\title{
Renminbi Internationalisation: Precedents and Implications
}

(A manuscript prepared for the Journal of Chinese Economic and Business Studies)

Dr. Damian Tobin ${ }^{1}$

Department of Finance \& Management Studies (DeFiMS), School of Oriental \& African Studies (SOAS), University of London.

Address for Correspondence: Dr. Damian Tobin, DeFiMS, SOAS, University of London, Thornhaugh Street, Russell Square, London WC1H 0XG, United Kingdom.

Phone: +44 207898 4821. Fax: +44 2078984058.

Email: dt29@soas.ac.uk.

(This Version: $23^{\text {rd }}$ October 2012)

\section{Abstract}

While it is commonly assumed that there are no known precedents against which to benchmark the internationalisation of the Renminbi (RMB), this paper argues that the PRCs own development provides a useful perspective on the internationalisation debate.

Specifically it indicates that lessons can be learnt from the successes and the shortcomings of efforts to internationalise the RMB in the 1970s. During this period Chinese state-owned banks in Hong Kong played a central role in mobilising finance for foreign trade. Access to Hong Kong's developed financial institutions allowed the PRC to maximise its receipts from foreign trade, promote the RMB as a stable currency that was likely to appreciate as well as minimise the risks of undue swings in capital flows. The paper shows that although China no longer faces foreign exchange scarcity, economic reforms have not yet resolved vulnerabilities in China's financial institutions. Unlike the 1970s China is no longer immune from market risk that might accompany a reduction in foreign residents RMB holdings. As such Hong Kong's banking system has retained its unique role as the location of choice for mitigating the risk of undue capital swings.

Keywords: China, Hong Kong, Renminbi, Currency Internationalisation, Banking Reform, Trade JEL: E42, F63, N10, O24

\footnotetext{
${ }^{1}$ The author would like to acknowledge the assistance of Professor Laixiang Sun (SOAS) and Professor Leo F. Goodstadt (Trinity College Dublin)
} 


\section{Introduction}

Taking the perspective that theory can only advance the understanding of pressing new macroeconomic developments so far, and that history is the only true laboratory for the study of pressing macroeconomic developments (e.g. Taylor, 2012); this paper argues that RMB internationalisation is best understood in the context of the long-term importance attached by the PRC to hard currency earnings as part of its objective of economic modernisation. This attachment has seen the China's economy shift from a shortage of foreign currency pre-1979 to a post-1979 surplus, but it has not necessarily resolved vulnerabilities in China's financial institutions. A comparison between the two periods shows that although China is no longer short of foreign exchange, the political reluctance to allow capital mobility remains. Moreover although the ideological opposition to openness has softened, what distinguishes the current policy conundrum is the scale and risk of capital outflow that greater capital mobility now implies. The paper also shows how in both periods the banking sector has been a key participant. In the 1970s the PRC’s Hong Kong-based financial institutions played a central role in solving severe foreign exchange shortages. Since 2004 Chinese state-owned financial institutions in Hong Kong have again been to the fore in offering non-deliverable RMB deposits, but it has ultimately been the pressing demand for further banking reform that has underpinned the need for further liberalisation.

China’s economic reforms have given an unprecedented access to foreign capital for a developing economy. By 2012 China had some 436,800 foreign invested enterprises with a registered paid up capital of US\$1.79 trillion. ${ }^{\mathrm{i}}$ Foreign exchange earnings from international trade have resulted in the accumulation of some US\$3.2 trillion in foreign exchange reserves. These two features contrast sharply with the PRCs position in the mid-1970s when there were widespread rumours regarding the perilous state of China's foreign exchange reserves and the potential inability of the PRC to pay for imports. ${ }^{\text {ii }}$ A report by the State Planning Commission in 1974 indicated that China's foreign exchange deficit for the first three quarters of 1974 would reach US\$1.2-1.4 billion and led to suggestions by Li Xiannian that China should consider the increased use of trade loans. ${ }^{\text {iii }}$ At the time, official attitudes to foreign currency loans were influenced by the view that foreign capital and loans were exploitative. In response to the shortage of foreign exchange PRC officials and in particular its state-owned banks - mostly those based in Hong Kong - made important efforts to accustom international investors to holding non-convertible RMB. They did so in an international economic environment that was not only volatile, having just emerged from the collapse of Breton 
Woods, but also one that was often hostile towards PRC interests. The efforts to accustom foreign investors to holding RMB bear a remarkable similarly to the contemporary RMB deposits in Hong Kong.

There is an additional notable feature that differentiated efforts in the two periods. In the 1970s, the PRC was able to promote the RMB as a currency that was likely to appreciate significantly, without exposing the PRC to external currency risk. ${ }^{\text {iv }}$ Officials could argue that the RMB enjoyed a stable purchasing power; it benefited from a centralised and unified system of currency issuance; and was free from the volatility associated with the currencies of capitalist countries. ${ }^{\mathrm{v}}$ Ideologically, such use of foreign capital could be justified on the grounds that it allowed China to exploit international finance for the benefit of socialist modernisation. In that way, PRC officials could easily differentiate themselves from what they viewed as the Soviet revisionists' apparent willingness to accept foreign trade credits. ${ }^{\mathrm{vi}}$ The PRC's rejection of ideology in 1978 and its replacement with market pragmatism meant that this differentiation was no longer credible. The subsequent running of large trade surpluses and accumulation of large US\$ reserves meant that the PRC was no longer immune from the risk of currency volatility and capital outflow. While China can still promote the RMB as an undervalued currency, it can no longer claim immunity from market risk that might accompany a reduction in foreign residents RMB holdings. ${ }^{\text {vii }}$ From a historical perspective it illustrated how much the role of international capital had changed and the scale of the new risks the PRC would face.

Despite the stark contrasts between both periods, the paper indicates that lessons can be learnt from the shortcomings of efforts to internationalise the RMB in the 1970s. In particular it provides an interesting perspective on the question of why China still faces the dilemma of balancing currency convertibility with economic control. In addressing this question the paper examines the connection between currency internationalisation, financial reform, and globalisation in developing economies. Section 2 explores the tension between maximising foreign exchange earnings and minimising risk in developing economies; its relationship to the banking system; the conundrum facing developing economies in opening their capital accounts; and the special institutional arrangements that are often required to do so. It also looks at the extent to which the offshore deposit market in Hong Kong has offered China a secure way of gradually internationalising the RMB. Section 3 looks at how the PRC resolved severe shortages of foreign exchange the 1960s and 1970s and how this led to efforts to achieve a greater internationalisation of the RMB. Section 4 explores the lessons 
from this period, in particular where it succeeded and what were its shortcomings. The paper concludes by arguing that the dilemma China now faces is much the same as in the 1970s in the sense that the question over how to achieve convertibility remains unresolved; but the risks of capital outflow are now significantly greater.

\section{Theoretical Background}

There exist many reasons why developing countries seek greater currency internationalisation. These range from the fundamental concern of financing foreign trade to concerns over the value of reserve currencies and foreign exchange exposures. For many developing economies, particularly those with weak financial institutions or facing economic sanctions and trade embargos, access to a predictable and stable flow of hard currency earnings is a pressing issue. Despite the phenomenal growth in cross-border financial flows over the past few decades, many developing economies remain short of the capital necessary to finance development (Prasad et al, 2003). The PRC’s own development experience indicates that the reasons why countries seek greater currency internationalisation may vary over time and according to the level of institutional development. It also shows how important are financial institutions in mobilising finance and trade settlement. The following section indicates that this is crucial in understanding Hong Kong's role as a source of foreign exchange earnings and as a location that offers the type of secure institutions capable of supporting an off-shore RMB market.

\subsection{Mobilising Cross Border Finance}

While economists have long known that institutions matter, it has been argued that in order to determine how and why, a source of exogenous variation in institutional quality is needed (Acemoglu et al, 2001). As delineators of wealth and poverty as well as the extent to which societies have attained their potentials, borders offer a powerful example of such variation (Baumol, 1990; Olson, 1996). For developing economies national borders also represent one of the most forceful examples of variation in the ability to mobilise finance. The PRC's border with Hong Kong was no different. Access to Hong Kong's free market helped mitigate the structural constraint that affected many developing economies of how to acquire foreign exchange earnings to maintain inputs and service debt and trade credit obligations (Diamond, 1974). The reasons for this are intuitive. External trade cannot be conducted without international exchange (Clauson, 1944). Exchange cannot occur without the financial institutions that issue and redeem currency as goods and services are traded. The exchange of 
currency often required elaborate and unusual institutional arrangements that extend beyond national borders. These have ranged from the Currency Authority that underpinned the British Colonial system to more recent schemes used by large banks to evade trade embargos. ${ }^{\text {viii }}$

Such unusual arrangements are themselves a product of weak domestic financial intuitions. Gershenkron (1962) highlights the case of $19^{\text {th }}$ century Russia as an example of the impossibility of building up a system of long term bank credit in a system where mercantile activities and deceit were inextricably connected. Bloomfield (1957) writing on the problems facing central banking in under-developed countries, argues that the growth in central banking in these countries was a reflection of their desire to pursue monetary policies that maximised economic development and mitigated undue swings in national incomes. The ability of these central banks to use open market operations to balance these two objectives was restricted by the limited scope of money markets in developing countries. In order to deal with such substantial and unpredictable fluctuations as large deposit withdrawals and bank runs, banks tended to maintain large reserves. The consequence of this liquidly concern was a short term focus on trade finance in their commercial operations and a preference for high reserve ratios.

For Gerschenkron (1962) remedying this problem required special institutional factors. He argued that the more backward a country was, the more likely it would need special institutional factors to increase the supply of capital to industry. This could come in the form of the role of banks in the industrialisation of Central Europe or indeed the Ministry of Finance in Russia’s industrialisation of the 1890s (Gerschenkron, 1962: 356). For pre-reform China, the special institutional factors that allowed the PRC to access hard currency were Hong Kong’s banking system (Goodstadt, 2006, Tobin, 2011). As part of the sterling area, Hong Kong was beyond the reach of the US embargo on the PRC and as such offered the only point of safe access to the outside world. Hong Kong's free market meant that it was a secure place to do business for China. This was facilitated by a special set of circumstances that allowed Hong Kong's colonial government to effectively turn a blind eye, or in some cases implicitly assist the development of a flourishing money market in Hong Kong. The predictability and efficiency of theses currency inflows that this delivered was crucial for China's survival (Goodstadt, 2007: 91). That they were also technically illegal from the perspective of the US (and the UK prior to 1967) and inconsistent with the PRC's ideological 
stance on money markets did not matter. For the PRC the fact that such money markets were illegal would merely have represented another contradiction in the capitalist system of finance.

Participation in these markets also introduced market-based risks into the system of central planning. Foreign exchange introduced normal market risk since trades took place outside the central plan. This risk can be conceptualised in terms of the dynamic commitment (Berglof and Roland, 1998) and time inconsistency problems (Kydland and Prescott, 1977). These refer to the discretion of policy makers to re-optimise their policy choices when they deem necessary, and the de-facto discretion of banks to respond opportunistically. China's banks were probably well aware of the moral compromises and the illegality of the sterling trade, but just like Hong Kong's officials, they were also aware that if the rules were strictly applied the banking system would not work. Consequently a lax approach was followed in banking regulation that was both based on economic rationality and facilitating Mainland interests. ${ }^{\text {ix }}$

Although economic reforms have since eroded many of the systematic differences between Mainland China and Hong Kong, it is significant that cross border interactions based on special and somewhat unusual institutional arrangements continue to characterise the internationalisation of the RMB. The quest for a safe place to do business remains a feature of China’s development. Hong Kong has offered China's indigenous entrepreneurs access to the efficient institutions of formal financing outside of Mainland China (Huang, 2008). China continues to view Hong Kong's role as central, not just for the window it provides for economic and trade exchanges between the Mainland and other countries, but also allows effective management of the risks associated with the cross-border trade (PBC, 2011:14).

\subsection{Sequencing, Openness and Development}

While the pre-reform economy relied very much what could be termed special institutional arrangements, the switch from foreign exchange shortage to surplus post-1979 has also shifted the debate towards how China can better manage inflows. Research now appears to indicate that were China to significantly increase its capital account convertibility, the RMB could become an important currency in international trade. Research by Chen (2007) indicates that given China's economic size, the RMBs position as an international reserve currency would be comparable to either the Japanese Yen or British Pound, possibly accounting for $3 \%$ to $5 \%$ of global reserves. Cui et al (2009) estimate that as much as $20 \%$ $30 \%$ of China's annual trade could be settled in RMB. The advantages of such a move are 
wide and varied, and range from the ability to diversity currency risk to making aid payments in its own currency. But there are also drawbacks. Full convertibility implies deliverability. This in turn implies that capital can flow more freely inwards, but it can also flow outwards. This introduces risks, the management of which depend on a fully functioning set of financial institutions.

One of the drawbacks of full capital account liberalisation that Chinese policy makers can readily cite is the very limited evidence on the relationship between financial openness and economic development. Although neo-classical economics has argued that long-term financial flows from capital rich to capital poor countries should generate welfare gains for both sets of countries, these benefits have ultimately proved difficult to quantify. A revised approach has instead argued that countries first need to reach a threshold of institutional development before they can hope to benefit from financial globalisation (Kose et al, 2006; Prasad et al, 2003). An IMF staff paper, which reviewed the evidence on capital controls and surges in capital inflows, indicated that capital controls are a legitimate part of the policy toolkit for managing inflows in such circumstances where the usual policy remedies are not appropriate (Ostry et al, 2010). ${ }^{\mathrm{X}}$ This includes scenarios where it is not possible to quickly address domestic financial fragility through the domestic prudential framework

The above concerns have been echoed by Chinese officials and economists. While the issue of exploitation by foreign capital largely ceased to feature in the literature after the 1980s, it was replaced by the question of how foreign capital could best be managed for China's benefit (Hsu, 1991, 134-136). There also appears to have an implicit acceptance that China has not yet reached the institutional thresholds that would enable it to fully benefit from capital account liberalisation. The Peoples Bank of China have highlighted the importance of reforming the RMB in a "self-initiated, controllable, and gradual manner" in the absence of full institutional development. ${ }^{\mathrm{xi}}$ Reflecting the views set out by the IMF, it has also been argued that controls on currency transactions ultimately helped to protect the economy from the instability caused by the 1997-1998 Asian Financial Crisis and sheltered the economy from the worst effects of the 2007-2009 Global Financial Crisis. Huang and Tao (2011) point out that many PRC officials remain concerned about the negative effects of currency appreciation, using the Japanese experience of economic stagnation following the Plaza Accord as a rationale. 
Alongside these concerns there has also been an acknowledgement of the inevitability of opening the capital account. Huang et al (2011) have argued that although close control over cross border flows initially benefited China, the costs of maintaining these controls have gradually increased. These include costs related to maintaining capital controls in an increasingly open economy and the associated loss of monetary independence. Ultimately they believe that capital account controls now represent a significant obstacle to China meeting its policy objectives of RMB internationalisation and turning Shanghai into a financial centre by 2015. This is consistent with the empirical evidence put forward by Chinn and Ito (2006), which indicates that trade openness is a prerequisite for capital account liberalisation and development of the banking sector is a precondition for equity market development. If these findings are applicable to China it is unsurprising that RMB internationalisation and banking reform are mow viewed as urgent priorities.

One of the puzzles of China's reforms is that despite significant trade openness, capital account transactions remain tightly controlled and its banking sector remains largely offlimits to foreign investors. By 2010 foreign banking assets accounted for a mere 1.85 per cent of total banking assets. The weaknesses of China's banking system are well known. After more than four decades of reform initiatives, the banking system remains dysfunctional having borne much of the costs of reforms (Goodstadt, 2012). Banking reforms have essentially been "needs driven”. As result the sector now faces a large reform deficit; the implication being that conventional prudential and monetary mechanisms cannot be relied upon to implement policy (Tobin, 2012). The extent of the reform deficit is such that it is believed that the link between bank financing and growth no longer holds and a large proportion of bank lending is now off-balance sheet (PBC, 2011). These deficiencies are important as they impede Shanghai's stated objective of becoming a global RMB trading centre, let alone its ambition to be an international financial centre. It has been argued that by ceding more voice to foreign interests, overseas investment in China's banking sector has the potential to markedly improve the performance of the banking system (Hope and Hu, 2006). However it is almost impossible to increase the participation of foreign banks or create a flourishing financial centre in the absence of capital account liberalisation.

\subsection{The Offshore Market in Hong Kong}

Given the weaknesses in the domestic banking sector, the RMB business in Hong Kong provides a useful testing ground for the expanded regional use of the RMB (Chen, 2007). 
Table 2 shows the rapid RMB deposits in Hong Kong since 2004 and as a means of trade settlement since late 2009. Many have have viewed this as a relatively benign growth, and a reflection of capital controls by Mainland authorises for which Hong Kong banks are well equipped to deal with given their diversified holdings of other asset forms. ${ }^{\text {xii }}$ The data show that China has increased the number of institutions permitted to offer RMB deposits in Hong Kong and used interest rate to manage the market as it has developed. McCauley (2011) argues that China departed from the conventional practice of ignoring the build-up of an offshore currency market. In this way Chinese policy makers have paid attention to its signals, implicitly recognising its inevitability and attempted to shape its development.

The development of an offshore market for RMB in Hong Kong and its possible extension to other financial centres such as London has provided an interesting new policy avenue for RMB internationalisation. ${ }^{\text {xii }}$ It offers monetary authorities both quantitative and marketbased tools (McCauley, 2011). China can control the quantity by adjusting the quotas for clearing banks and they can affect the yield by varying the interest rate that the Peoples Bank of China pays clearing banks for deposits. In ensuring that it can adequately control the offshore market, China has used its own state banks in Hong Kong. In December 2003 the Peoples Bank of China authorised the state-owned Bank of China (Hong Kong) as the clearing banks for personal RMB business under the Clearing Agreement on RMB Business. As the following section will show, the Hong Kong branch of the Bank of China has had a long role in coordinating the PRC's external foreign exchange policy. China has also sanctioned a non-deliverable virtual currency forwards market. While it not clear the extent to which authorities can control this market, efforts at control may include e influence over state-owned banks and large state corporations which trade as counterparties to foreign investors (MaCauley, 2011).

But the process of RMB internationalisation is not without risk. Although RMB deposits in Hong Kong are non-deliverable, there are specific risks for both Hong Kong's banking sector and the ability of Chinese policy makers to exercise the same level of control over the offshore market, particularly in the event that it becomes deliverable. Potential risks are best illustrated in periods of volatility. For example, RMB deposits reached RMB 77,640 billion in the second quarter of 2008, but subsequently declined to RMB 53,110 billion in quarter 1 , 2009, before finishing 2009 at RMB 62,718 billion. This volatility was attributed to speculation about changes in the RMB exchange rate and the launch of RMB denominated bonds. During this period the ratio of demand to time deposits was generally 2:1. Although a 
degree of maturity mismatching is inevitable, a large proposition of demand deposits can give rise to a liquidity (or refunding) and interest rate risk, unless the risk can be offset to borrowed using variable loan interest rates (Mullineux, 2011). In 2010, there was a sudden increase in the share of RMB deposits as a percentage of total Hong Kong deposit from 2.4\% to $11.5 \%$. This was attributed to an increase in corporate RMB receipts in trade settlements and also expectation of appreciation in the value of the RMB. During this period the number of institutions offering RMB deposits expanded rapidly and the interest differential between time and demand interest rates appeared to widen (Figure 1). The period also witnessed a reversal in the ratio of demand to time deposits to a more stable ratio of 1:3.

In August 2012, RMB deposits in Hong Kong were reported to have fallen by $1.9 \%$ as trade remittances to Mainland China increased. ${ }^{\text {xiv }}$ While such declines are can be viewed as a normal part of Hong Kong growing role in RMB trade remittances (Table 1), RMB deposits now represent a substantial part of Hong Kong banks funding base. By Quarter 2 2012, RMB deposits accounted for some $17.5 \%$ of deposits in Hong Kong having grown from just 1.1\% in 2004. Since the growth of RMB deposits ultimately affects the ability of Hong Kong banks to finance increases in their loan books and further extend RMB investment products, it would appear there are risks attached to having a deposit base denominated in a nondeliverable currency whose quantity is subject to swings in trade remittances and exchange rate speculation. With few appropriate comparisons it is possible to view these developments as having a relatively benign impact on Hong Kong’s developed financial sector.

Alternatively they could be viewed as an early warning of the likely difficulties that China will face should its capital account become convertible.

(Table 1 and Figure 1 here)

\section{The Historical Precedent}

Recent efforts to have the RMB accepted as an international currency of exchange have an interesting precedent from the pre-1979 economy. Efforts in the 1970s to accustom international investors to holding RMB were influenced by a number of factors in the domestic and international economy. Following the Korean War (1950-53) the US froze many of the PRC's external assets and as a result the PRC held a large proportion of foreign reserves in sterling (Donnithorne, 1967). For Hong Kong, there was a widespread perception that PRC involvement in the Korean War effectively cast into doubt Hong Kong's future as an entrepôt economy following the sealing of its border with the PRC (Catron, 1972, Sung, 
2005). From 1960 onwards the Sino-Soviet dispute witnessed a rapid reduction in trade with the USSR. The consequence of these events and the ideological reluctance to accept international loans and trade credits was an increasing reliance on hard currency earnings. Similarly, economic crisis in Western economies in the 1970s and the desperate need to modernise industry meant that having the RMB accepted an international currency of settlement carried enormous appeal. The following describes how the international operations of China's state-owned banks in Hong Kong had already begun to actively promote the RMB as one of the few stable currencies by offering RMB deposits. It also describes how Chinese officials were astute observers of the problems facing international financial markets. They were also able to resolve key ideological obstacles to trade and investment financing. This is illustrated in their ability to resolve such conundrums as how to find a formula to allow SinoJapanese trade to be conducted in RMB and Yen.

\subsection{Banks, Export Competitiveness and Finance}

Under the PRC's pre-reform economy there was a strong relationship between state-owned banks and export competitiveness. The banking system, particularly its Hong Kong branch, played a central role in maximising foreign exchange receipts from trade, protecting China's foreign exchange assets by maintaining a watchful eye on the international monetary environment, and maintaining good links with the international banking community. It carried out there functions primarily for the benefit of China's state-owned trading corporations. Despite their communist allegiances, PRC Officials were well informed on the problems facing western banks during the 1970s and how this affected the performance of these economies. Official media routinely outlined how this was a consequence of unstable money markets in these countries and the dangers that banking collapses posed to the economy. ${ }^{\mathrm{xv}}$ It is unsurprising therefore that the PRC placed great emphasis on financial system stability and on the moral standing of the individuals charged to run these institutions. What is surprising is how well these officials were able to predict market developments and use them to the PRC's advantage.

At the centre of China's international banking system was the Hong Kong branch of the Bank of China, the bank that was in 2003 designated as the clearing banks for RMB deposits in Hong Kong. The Bank of China was the specialised foreign exchange bank of the PRC, performing the entire task of settling the PRC's international payments. ${ }^{\text {xvi }}$ Its main function was financing China's external trade. Its main business was trade financing and it by and 
large avoided any involvement in commercial lending. As such an important distinction between the bank balances of Hong Kong's commercial banks and PRC banks was that the balances of the latter mostly represented a surplus of trade conducted through state-owned trading companies in Hong Kong. This surplus was deposited with the bank’s head office in Peking in the name of the Hong Kong Branch. Part, but not all, of these funds were used to purchase sterling, mainly through the Hong Kong and London branches of the Bank of China, to pay for imports. The significance of these locations was that as part of the sterling area they were beyond the reach of the US legal institutions. State-ownership of trading companies implied that all balances can be thought of as effectively due to Peking. As such bank balances represented a trade credit facility for the PRC.

Although the PRC's trade credit facility operated beyond the reach of US legal institutions, the process was effectively illegal under the UK's Defence (Finance) Regulations. The Defence (Finance) Regulations imposed exchange controls on Hong Kong and first came into force when the Colony joined the sterling area in $1941 .{ }^{\text {xvii }}$ Colonies were required to exert careful control and share information on sterling supply within the sterling area and nonsterling exports. ${ }^{\text {xviii }}$ The operations of PRC banks therefore created a mismatch between the controls imposed in the rest of the sterling area and what was happening in Hong Kong. For Hong Kong such requirements were also cumbersome as many of its raw materials were sourced outside the sterling area. For example trade with Mainland China relations pre-dated the establishment of the PRC in 1949. While Hong Kong could in geneal avoid dollar-based purchases; in practice this was not always be possible. ${ }^{\text {xix }}$ An example of this was the cotton trade. China was principal source of Hong Kong's pre-war supply and although China was in the late 1940s increasingly short of raw cotton and foreign exchange as the KMT regime collapsed, China was anxious to maintain the Hong Kong market. ${ }^{\mathrm{xx}}$ Part of the incentive for China to maintain the Hong Kong market was the prospect of earning sterling; part was to keep cheaper Japanese yarn out. ${ }^{\text {xxi }}$ For these reasons China expressed a willingness to sell to Hong Kong through official channels at a price below that available elsewhere. Although the KMT regime subsequently collapsed, the policy of maintaining the Hong Kong market through competitive prices remained, even under communism.

\subsection{Maximizing Development, Minimizing Risk}

The PRC's determination to maintain Hong Kong as a source of foreign exchange was not solely based on price competitiveness. It was also based on the need to maximize its 
development prospects via the accumulation of foreign exchange while at the same time minimizing the external risk to the PRC. It achieved these often conflicting objectives by applying hard economic principles to decisions on monetary policy, and by relying on staff who had demonstrated their loyalty to communist values and who had an expert knowledge of international foreign exchange markets. Although in practice this meant that the PRC's Hong Kong banks had the trade and liquidity preference outlined by Bloomfield (1957), it also meant that the problems of dynamic commitment and time inconsistency in policy did not arise.

The ability to apply hard economic principles was illustrated following the the devaluation of the pound sterling and the Hong Kong dollar in November 1967. Media reports suggested that there was a widespread belief that if sterling were devalued, the PRC would ultimately follow suit. ${ }^{\text {xii }}$ These beliefs were based on the assumption that there existed a strong political rationale for China to absorb the cost of such devaluation. The cost was a loss of foreign exchange earnings. But not raising prices would win a political advantage and help repair some of the reputational damage following the communist riots earlier in that year. This did not happen. The Bank of China revalued the RMB against the Hong Kong dollar and compensated itself fully for the loss in earnings brought about by sterling's devaluation. The action was entirely rational in the sense that it effectively defended the real value of its exports to Hong Kong, but in doing so it also passed on inflationary pressures. Not only did it do this, but Chinese stores in Hong Kong also raised prices by about 15 percent. ${ }^{\text {xxiii }}$ It is clear that PRC officials believed that Hong Kong could afford higher prices. They may have been aware that the PRC exports were comparatively inelastic due to domestic production constraints and would not have been able to compensate for any loss through increases in quantity.

The revaluation of the RMB in 1967 illustrated the priority that the PRC attached to maintaining foreign currency earnings. China's trade surplus with Hong Kong allowed it to run deficits with other countries. Jao (1983) shows that had China not run a surplus with Hong Kong, China would have run substantial trade deficits in at least 24 years of the period 1950-1980. The approach could be explained by the fact that the predominant part of China's imports during this period consisted of plant and machinery, grains, raw materials and fertilisers, all of which were supplied directly to China from countries such as Japan. During the period 1961-73 Hong Kong benefited greatly from PRC imports citing research which 
showed that Hong Kong's cost of living would have been at least 15\% higher for the same level of consumption (Jao, 1983:23). In this context the revaluation and subsequent price increase appears to be based on a careful consideration of the economic consequences. It also illustrated the astuteness of the PRC's monetary policy. This was again illustrated in the ability to predict the stability of sterling in 1971 and the weakness of the US dollar in 197172 and its subsequent revaluation. ${ }^{\text {xxiv }}$

The PRC could not however have effectively balanced the risks and rewards in such a way without highly competent banking officials who were willing to work with their foreign banking counterparts without compromising on their ideological beliefs. For example, during 1967 the demand from the Bank of China for sterling was such that HSBC had to buy US Dollars, to convert to sterling and negotiate an emergency government issue. There was an increase of HK\$600 million (£37.5 million) in local note issue between May and July 1967 to meet this demand (Schenk, 2009: 113). Neither could the PRCs monetary assessments be so accurate without staff that had intimate knowledge of overseas banking practices as well as domestic economic and political developments. One such banker was Zheng Tieru (known in Hong Kong as Shou Chen). Zheng studied economics in the US before joining the Bank of China in Guangdong Province in 1922. Zheng was regarded as an expert in international banking and a personal friend of Zhou Enlai. ${ }^{\mathrm{xxv}}$ He managed the Hong Kong branch for almost 30 years until 1966. His achievements included overseeing the Hong Kong operations of the Bank of China prior to 1949, and ensuring their safe transition to state-ownership under the CCP in 1949. ${ }^{\text {xxi }}$ His leadership was illustrated both by the respect he enjoyed among leading private sector entrepreneurs in Hong Kong and his close connections to the political system in Beijing. Zheng's successor, Li Choh-chi enjoyed a similar background. ${ }^{\text {xxvii }} \mathrm{Li}$ guided the Bank through the chaos of the Cultural Revolution and the sterling crisis of 1967. The ability of the Bank to maintain and honour all deposits was testament to the management's ability to manage conflict despite political hostilities.

\subsection{The RMB as a Stable Alternative}

The scale of investment needed to modernise industry meant that by the beginning of the 1970s the aversion to international loan finance that had characterised the early development of the PRC became less feasible. Beginning in 1968 the PRC began to actively promote the RMB as currency for price quotation and trade settlement. ${ }^{\text {xxviii }}$ Such efforts increase in response to growing uncertainly in the global monetary environment following the ending of 
the Breton Woods Gold Standard in 1971 as well as changes in the international banking environment. Greater internationalisation of the RMB would have provided a degree of stability in what was a very uncertain monetary environment. In achieving this, the PRC once again befitted from both an assertive banking system and an astute monetary policy. Chinese state-owned banks actively engaged in efforts to repair their relationships with the international business community. During this period the PRC followed a foreign exchange policy based on combination of stable domestic prices and an overvalued Yuan, the result of which led to financial losses for many exported commodities when measured in domestic currency (Lardy, 1992). But this policy meant that it was easier to market the RMB as a stable currency that was likely to appreciate in value.

In promoting the RMB as a stable alternative to other international currencies, PRC banks in Hong Kong expanded their branch networks and offered attractive interest rates. Between 1969 and 1978 the Bank of China and its sister banks (also under state ownership) increased their branch numbers from 57 to $123 .{ }^{\text {xxix }}$ Such increases were only possibly by exploiting a loophole in Hong Kong’s banking regulations, which restricted the increase of foreign banking entities in the colony. The Bank also went against the local trend of interest rate reductions. ${ }^{\mathrm{xxx}}$ In October 1974 the Bank of China in Hong Kong raised its six month deposit rate to 7 per cent, an increase of $2.5 \%$ on the previous rate. The interest rate on one year deposits was raised to 8 per cent up from 5.75 per cent and the interest rate on three year deposits was increased to 8.5 per cent from $6.75 \%$ per cent. By offering a higher interest rate the Bank hoped to attract back depositors following the outflow and loss of confidence that occurred during the early years of the Cultural Revolution. Such deposits were in nonconvertible currency whose export was strictly forbidden by PRC law. However, there was a book entry at the Mainland bank which entitled the depositor to receive a sum in Hong Kong dollars (not RMB) to be calculated at the expiry of the deposit's tenor at the prevailing rate of exchange between the RMB and the Hong Kong dollar. It is also interesting how the activities of the Hong Kong banks coincided with efforts in 1974 to normalise economic life on the Mainland. These efforts included export promotion and import substitution, the increase use of foreign trade loans and the sales of Chinese gold reserves (Reardon, 2002: 174-75). Figure 2 shows the changes in the banking model of Hong Kong branch Bank of China over the period 1964 to 1980. During this period it not only rapidly expanded its deposit base, but it also began to engage in lending thus moving away from its original focus 
on trade finance. Figure 2 also shows how this coincided with an increase in the PRCs external trade from 6.7 percent of GDP in 1964 to 12.5 percent in 1980.

\section{(Figure 2 here)}

While attracting non-deliverable deposits offered an ideologically acceptable way of raising finance, the internationalisation of RMB raised an important dilemma. This related to the PRC's ideological aversion to capitalist trade. Financing industrialisation or the transfer of foreign technology through foreign credits was viewed by officials as running the risk of importing capitalist inflation into the cost structure of the socialist economy. ${ }^{\text {xxxi }}$ The preference for hard currency earnings was a clear indication of how China wanted to pay its way in international trade. This intention illustrated in the early 1970s as China sought to increase its imports of industrial plant and machinery. In January 1972 China rejected an offer of trade credits to purchase a vinylon plant from Japan. ${ }^{\text {xxxii }}$ But resolving the dilemma was also vital to reduce the uncertainly that faced large state trading companies in trading with their largest customer Japan. Up to the 1970s most of the trade with Japan was invoiced in sterling. It is no surprise that China's risk adverse trading corporations and their Japanese trading partners would have a preference for moving away from sterling. In 1972 following a normalisation of trading relations with the US, the PRC began to use a combination of export promotion and short term foreign exchange loans to finance the purchase of foreign plant and machinery as part of a large scale import substitution development strategy (Reardon, 2002: 157-162). A substantial proportion of these loans were funded from the deposits held by the Bank of China in Hong Kong, a move that vastly increased China's ability to import plant, but remained consistent with China’s aversion to capitalist trade financing.

The shift was reinforced by Deng Xiaoping, who in reiterating the validity of the Four Modernisations, stressed the need to import advanced technology in order to speed up the technical transformation of industry. ${ }^{\text {xxiii }}$ Acceptable means of financing this included deferred payment. ${ }^{\text {xxiv }}$ The acceptance of the RMB appeared an important element of this. In 1974 China agreed to purchase from the Japanese synthetic fibre maker Teijin Ltd a ¥5,000 million polyester fibre plant. ${ }^{\mathrm{xxx}}$ The plant would be paid for in Yuan over a five-year period. On the Japanese side the deferred payment side of the deal was to be financed by a loan from the Export-Import Bank of Japan. The key to this deal appears to have been both the willingness of Japan to accept the Chinese Yuan as a means of invoicing and China's willingness to enter into a deferred payment agreement. Writing contracts for foreign plant 
purchases has the effect of removing some of the uncertainty in the international monetary environment at the time. This was an uncertainty that PRC officials viewed as a fundamental fault in the workings of the capitalist system and one that was used to exploit developing economies. In doing so it resolved the pressing dilemma facing Sino-Japanese trade, namely how to move away from the reliance on settlement in sterling. It was also an example of the willingness of Japan to accept the RMB as a currency of trade settlement.

The shift to deferred payments was also accompanied by a more general recognition that the Chinese economy suffered from being cut off from the outside world. By 1975 trade deals were not only based on deferred payments, but also denominated in US currency. ${ }^{\text {xxvi }}$ By 1977, Jao (1983: 26) points out that outstanding trade credits amounted to some US\$1,315 billion and Chinese officials now viewed them as a standard commercial practice. This went further towards removing the antagonism towards foreign borrowing. ${ }^{\text {xxxvii }}$ Innovations such as the use of a mutual deposit scheme whereby the Bank of China and other foreign banks would deposit funds with each other in their respective national currencies, with the foreign banks depositing more, essentially amounted to a de facto inter-bank loan (Jao, 1983). By 1979 official sources were quoted as acknowledging that the type and scale of projects that China needed to fund for further modernisation were simply too large to be solved with private level economic cooperation and that national level financing in the form of loans and trade credits would in future be necessary. ${ }^{\text {xxxvii }}$ The projects cited included iron ore port facilities, railways, hydroelectric power stations. It was also recognition that despite the advances achieved under self-sufficiency, the gap between Western and Chinese technology, even in sectors such as petrochemicals which had benefited from Japanese trade credits, could not be bridged without full access to foreign expertise (Kambara and Howe, 2007). In practice this meant foreign direct investments rather than capital account convertibility. The direction of future policy was clearly set out in 1980 under the Provisional Regulations for Exchange Control, which emphasised the spirit of control and promotion. Control referred to centralised rules on the amount of foreign exchange that localities would be allowed to retain and limits on its use for private gain; promotion referred to efforts of localities and enterprises to earn foreign exchange. ${ }^{\text {xxxix }}$

\section{Policy Implications}

The account of the efforts to have the RMB accepted in foreign trade is interesting both for why it was successful and why it failed. The efforts were successful to the extent that they 
allowed China stability and predictability in its international trade relations, particularly with Japan. Efforts to raise deposits in Hong Kong and rebuild relationships with the local business community following the Cultural Revolution were also successful. PRC banks were able to market a stable currency that had very limited downside. Ideologically the policy was acceptable as the RMB was non-deliverable and there was little chance of outflow. However its shortcoming was that the scale of finance required for China's modernisation was simply too large. Private level cooperation with limited currency risk was simply too small for the ports, railways and power stations that the transition from a pre-industrial society required. It also failed because the desire to retain control over the national currency and ultimately a fear of foreign exploitation remained intact. The switch to FDI in the 1980s and the adoption of a control and promotion strategy meant that the PRC was able to find an alternative way to finance its modernisation, but it left unresolved the issue of greater RMB internationalisation. The implications of this shortcoming are that the capital account mobility has remained tightly controlled and largely restricted to FDI inflows with a minimal role for foreign financial institutions.

One of the significant successes of the pre-reform period was the ability of China's stateowned banks in Hong Kong to manage the link between monetary policy and national competiveness. In the late 1960s PRC officials demonstrated an astute awareness of what effect a revaluation of the RMB would have on Hong Kong's economy. This awareness was ultimately built on a banking system that sought to maximise foreign exchange returns but mitigate any risks that operating in capitalist markets entailed. It is interesting that even today; the question remains one of critical economic importance. For example, in the aftermath of the Global Financial Crisis, Chinese officials virtually ignored attempts to pin the blame for the crisis on them. Instead their major concern was a return to protectionism in their major export markets (Tobin, 2011). Secure market access has been a long term priority in achieving socialist modernisation. So too has balancing the need for foreign exchange earnings with that of mitigating the effects of undue swings in capital flows. But the downside of this is that just as the issue of self-sufficiency and a die-hard opposition to allowing foreign investment in oil and gas resources that required any kind of foreign ownership or access to land long remained a stumbling block to progress in those sectors (Kambara and Howe, 1997); so too does the issue of allowing the free export of RMB.

There is also a remarkable similarity between the international economic environment faced by the PRC in the early 1970s and its effect on foreign exchange earnings, but a notable 
difference in the competitive challenge faced. The international economic crisis in the 1970s undoubtedly dampened demand for the PRCs exports, though Reardon (2002: 174) points out that the State Planning Commissions own assessment placed the blame on the economic disruption caused by the 1974 Anti Lin/Anti Confucius campaign. These included the shortage in export commodities and higher vessel rental fees caused by port disruptions. However despite these setbacks, the economy emerged from the Cultural Revolution in surprisingly good condition. Wages were 7.2 percent lower in 1976 than they had been in 1965. Retail prices had fallen by 1.7 percent, and the gross value of industrial output rose by an annual 15.7 per cent in real terms. The gross value of agricultural production increased by 4.6 percent in real terms, while foreign trade expanded by 19.7 percent a year in US dollar terms. ${ }^{\mathrm{xl}}$ However unlike the 1970s, the onset of the 2007-2009 Global Financial Crisis has witnessed a slowing in the growth of China's current account surplus, while domestic policy measures have simultaneously sought to manage FDI inflows and encourage greater outward FDI (Table 2). In the run up to the crisis, China’s economy also appeared to be suffering from rising costs and slowing productivity. From 2004-2008, average manufacturing wages grew by 14.1 per cent while labour productivity grew by 10.7 per cent. ${ }^{\text {xli }}$ Taken together, these developments indicate that although the global contexts for internationalisation were somewhat similar, the domestic policy challenges driving internationalisation are very different.

From this perspective, the off-shore deposit market in Hong Kong appears to offer the type of unconventional arrangement that can act as a buffer for the domestic banking system while at the same time facilitating a greater RMB internationalisation. However like its counterpart in the 1970s, it does not necessarily offer a new way forward. In the 1970s the solutions involved trade credits, non-deliverable deposit accounts, mutual deposit schemes, international loans and ultimately FDI inflows. However they stopped short of allowing free movement of capital. Any further liberalisation will imply that capital can as easily move outwards as inwards. It is this point that clearly differentiates the current challenge from that faced in the 1970s. In its relatively short period as a significant creditor nation, China has accumulated a net international asset position that is converging with Japan and a net long foreign currency position of almost 60\% GDP (Cheung et al, 2010: 2). The latter has arisen mainly as a result of the non use of RMB by non-residents. This issue has been less of a problem for Japan as its currency is also used by non-residents. For China this risk has been amplified by a cycle of monetary tightening, expectations that greater inflows of US\$ and 
interest rate rises will lead to a RMB appreciation and a subsequent greater incentive for foreign enterprises to hold RMB. These risks were illustrated in 2011, when China reported an unprecedented net outflow of US\$3.1 billion. ${ }^{\text {xlii }}$

A final but vital consideration is that of banking reform. Both theory and the evidence presented in this paper suggest that a fully functioning banking system is the unavoidable component of greater capital account convertibility. It is inextricably linked to the target of turning Shanghai into a global RMB settlement centre. Greater capital account convertibility is itself a precondition for the greater participation of foreign banks. In this regard, it is somewhat remarkable that both official and independent scholarly accounts give relatively scant attention to the role of banks in China's economic take-off (Goodstadt, 2012). Scholars have pointed out how in the period 1979-1983 the Bank of China actively began to engage in international borrowing to finance PRC infrastructure projects (Kueh and Howe, 1984: 823); but by and large the focus of authoritative accounts has been how economic reform went hand in hand with a decentralization of control over international trade and its proceeds from central to local government (Solinger, 1993). By the end of the 1990s however it was clear that banks were one of the least reformed sectors of the economy. In the past stable financial institutions played a crucial role not just in mobilising finance, but also in mitigating the structural risks that developing economies typically face in international trade. While it remains possible for the PRC to maintain control over the money market in Hong Kong through quotas and interest rates, it is unclear how this control would translate were China to experience a significant outflow of funds.

\section{(Table 2 here)}

\section{Conclusion}

The analysis presented in this paper illustrates the long term value placed on the Hong Kong market by the PRC. Access to Hong Kong's developed financial institutions has allowed the PRC to maximise receipts from foreign trade as well as minimise the risks of undue swings in capital flows. This access has allowed the PRC mitigate some of the longstanding structural constraints that typically face developing economies. The role of the PRC's banks in helping to mitigate this constraint is particularly interesting given the well-known problems that the sector now faces. The analysis also presents some policy implications for contemporary approaches to RMB internationalisation. The concern over finding an acceptable method of RMB liberalisation remains paramount, as does the dilemma of how to achieve greater 
internationalisation without damaging export competitiveness. The analysis in this paper has shown how in the past the banking system, particularly the international side, adopted a strong interest in ensuring the competitiveness of Chinese exports. Its role appeared crucial in managing the exchange rate mechanism in China's national interest. The growth of RMB deposits in Hong Kong indicates that China continues to see a strong role its state banks in the greater international use of the RMB, but it is unclear how in the absence of domestic financial reform this can translate into improved economic performance. This analysis suggests that the important difference between the pre- and post-reform regime is that under the former the CCP used moral authority and affinity to communist values to mitigate moral hazard and risk of outflow within the foreign exchange system; under the latter it must rely on market disciplines. As such the ability to control such outflows cannot be assumed in the absence of fully developed financial institutions. In the absence of the latter, it is likely that Hong Kong will continue to act as a buffer between the domestic and international banking systems.

\section{Notes}

\footnotetext{
${ }^{\mathrm{i}}$ Reported Xinhua (New China News Agency, NCNA hereafter) $21^{\text {st }}$ September 2012

${ }^{\text {ii }}$ See for example 'Meeting with Deng' Kyodo $20^{\text {th }}$ January 1975 in which Japanese media reported on trade negotiations between Japan and China where China's then vice premier Deng was forced to deny that China's foreign exchange reserves had dropped dramatically. He went on the make an oblique warning that future Sino-Japanese trade deals may fall through if Japan believed that China did not have the capacity to pay.

iii The efforts also included a normalisation of the foreign trade sectors by increasing certain exports and reducing imports. See Reardon 2002: 174-175.

${ }^{\text {iv }}$ During the period 1971-79 the PRC re-valued the RMB steadily upwards from 2.46/US\$ to 1.49/US\$ (Lardy, 1992:66)

v 'PRC remains free of inflation, currency stable' NCNA $21^{\text {st }}$ September 1974

${ }^{\text {vi }}$ See for example “Soviet’s ‘Materialisation of Détente’ viewed” NCNA $1^{\text {st }}$ March 1976

${ }^{\text {vii }}$ For an outline of the risks associated with a combination of revaluation pressures, credit tightening and the holding of RMB offshore see 'Renminbi Internationalisation a one-way street' (Hong Kong) Economic Journal Insight $18^{\text {th }}$ February 2011.
} 
viii Large international banks have in the past used complex and elaborate schemes to allow clients in such countries facing US sanctions as Iran, Libya, Sudan, Myanmar and Cuba to trade in US dollars. See ‘Tallying Up U.S. Regulators’ Money-Laundering Fines’ New York Times $15^{\text {th }}$ August 2012. ${ }^{\text {ix }}$ Such exchange transactions were only illegal because the Hong Kong government had not granted a licence or simply forgot. It had proposed legalising the trade in 1958 but London objected on account of US concerns.

${ }^{\mathrm{x}}$ The authors also point out that to be effective such controls should where possible internalize the systemic dangers that could result from a widespread adoption of such controls.

${ }^{x i}$ See for example China Monetary Policy Report Quarter 1, 2011 (PBC, $3{ }^{\text {rd }}$ May 2011)

xii See the comments of Hans Genberg SCMP $18^{\text {th }}$ November 2010

xiii Although there has been much positive comment about London's potential role as an off-shore settlement centre, London's potential is limited by the lack of the a combination of a currency sway agreement and a RMB clearing bank See 'London becoming international RMB trade hub still a long way off' China Securities Journal $21^{\text {st }}$ February 2012.

${ }^{\text {xiv }}$ NCNA 29 ${ }^{\text {th }}$ September 2012

${ }^{x v}$ NCNA: Many US, W European Banks in Financial Straits 24 ${ }^{\text {th }}$ October 1974

xvi Chou Chen-Hsing, Bank of China (1978: 97)

xvii Hong Kong Hansard 26 $6^{\text {th }}$ April 1967

xviii These concerns are outlined in circulars from the Secretary of State for the Colonies during the early 1950s: CR19-2321-52 Import Licensing Policy for Dollar Imports (Hong Kong Records Service (HKRS hereafter) 163-9-98)

xix Remarks by Hong Kong's Governor in 1948. Recorded in a Savingram to Secretary of State for the Colonies from Governor of Hong Kong in files on Cotton Textiles 29-12-1948 (HKRS 41-13378)

${ }^{x x}$ Files on Cotton Textiles 29-12-1948 (HKRS 41-1-3378)

${ }^{x x i}$ Cotton yarn from China tended to be more expensive as shipping was shared with China on a 50:50 basis thereby lessening the foreign exchange benefit to China; and also because of the tendency for Japanese yarn to be of a higher quality and yarn bales overweight as opposed to Chinese bales, which tended to be underweight. Savingram to Secretary of State for the Colonies from Governor of Hong Kong in files on Cotton Textiles 29-12-1948 (HKRS 41-1-3378)

xxii “As Peking Saw It” Far Eastern Economic Review, 11 ${ }^{\text {th }}$ April 1968

xxiii Far Eastern Economic Review 11 ${ }^{\text {th }}$ April 1968

xxiv Far Eastern Economic Review Vol. 76, No. 14, 1 Apr 1972

${ }^{x x v}$ An account of Mr Zheng's background and affinity to the CCP can be found in the memoirs of the economist Qian Jiaju. Hong Kong Mingpao Yuekan (Ming Pao Monthly) No 227 January 1989 (pages 29-35). 
${ }^{\text {xxvi }}$ A confidential letter from Mr. Zheng to the Hong Kong Government on $12^{\text {th }}$ July 1948 outlined concerns regarding political developments in Mainland China and their implications for the Bank of China in Hong Kong. See HKRS163-1-756 Correspondence regarding the modification and design of the BOC building

xxvii 'Bank of China manager dies’ South China Morning Post (SCMP) 18 September 1974

xxviii ‘PRC remains free of inflation, currency stable’ NCNA (Peking) $21^{\text {st }}$ September 1974

${ }^{\text {xxix }}$ See file HKRS 411-2-45(2)

${ }^{\mathrm{xxx}}$ see file: HKRS 70-6-91 Banks and Banking

${ }^{x x x i}$ Chia Shu-Fan PRC Foreign Trade Official denies Deficit financing La Stampa (Italy) $18^{\text {th }}$ May 1975

${ }^{\text {xxxii }}$ Far Eastern Economic Review Vol. 76, No. 14, 1 Apr 1972

xxxiii See Deng Xiaoping 'Some Comments on Industrial Development', $18^{\text {th }}$ August 1975

xxxiv Deng highlighted the case of the coal industry where he suggested the import of advanced mining technology under long term contract to be repaid using coal exports.

${ }^{x x x v}$ Polyester Fibre Plant, Kyodo (Tokyo) $8^{\text {th }}$ February 1974

xxxvi The China National Chemicals Import and Export Corporation signed a deal to purchase some 500,000 tons of urea and 220,000 tons of ammonium sulphate for US\$100 million based on 60 deferred payments in August 1975. 'Japan, PRC reach accord on Fertilizers' Kyodo 21 ${ }^{\text {st }}$ August 1975 xxxvii Li Hsien-nien (Chinese Vice-Premier) reported in London Financial Times, 30 June 1978.

xxxviii Possible Loan Request, Kyodo (Tokyo) $2^{\text {nd }}$ September 1979

xxxix ‘Strengthen Foreign Exchange Control to Promote the Four Modernisations' Renmin Ribao, Editorial, $30^{\text {th }}$ December 1980.

${ }^{\mathrm{xl}}$ The statistics that follow are taken from the State Statistical Bureau, Statistical Yearbook of China 1983, pp. 17, 420, 455, 490.

xli See China Monetary Policy Report (2010: page 44).

xlii NCNA $23^{\text {rd }}$ February 2012 


\section{Bibliography}

Baumol, W.J. 1990. Entrepreneurship: productive, unproductive and destructive, Journal of Political Economy, 98, 893-921.

Berglof, E. \& G. Roland, 1998. “Soft Budget Constraints and Banking in Transition Economies”, Journal of Comparative Economics, 26 (1): 18-40.

Bloomfield, A.I. 1957. 'Some problems of central banking in underdeveloped countries,' Journal of Finance, 12 (2): 190-204.

Catron, G. 1972. “Hong Kong and Chinese Foreign Policy”, 1955-69, The China Quarterly, No. 51 (July-September): 405-424

Chen, H. \& W. Peng. 2007. 'The Potential of the Renminbi as an International Currency' China Economic Issues (Hong Kong Monetary Authority) Vol. 7/07 (November)

Cheung, Y.W., G. Ma, \& R.N. McCauley. 2010. 'Renminbising China’s Foreign Assets' HKIMR Working Paper No.16/2010

Chou, C.H. 1978. Bank of China and the settlements of international payments in China's foreign trade and its management. Hong Kong: Chung Hwa

Clauson, G.L.M. 1944. 'The British Colonial Currency System’ The Economic Journal, Vol. 54(213): 1-25.

Cui, L, S. Chang, \& J. Chang. 2009. 'Exchange Rate Pass-Through and Currency Invoicing in China’s Exports,' China Economic Issues, No. 2/09.

Diamond, J. 1974. 'The analysis of structural constrains in developing economise: A case study’ Oxford Bulletin of Economics and Statistics, 36 (2): 95-108.

Donnithorne, A. 1967. China's Economic System. London: Allen and Unwin

Gerschenkron, A. 1962. Economic Backwardness in Historical Perspective: A Book of Essays, Cambridge: Harvard University Press.

Goodstadt, L.F. 2006. 'Painful Transitions: The Impact of Economic Growth and Government Policies on Hong Kong’s ‘Chinese’ Banks, 1945-70’ Hong Kong Institute of Monetary Research Working Paper No. 16/2006

Goodstadt, L.F. 2007. Profits, Politics and Panics: Hong Kong's Banks and the Making of an Economic Miracle, 1935-1985. Hong Kong: Hong Kong University Press. 
Goodstadt, L.F. 2012. 'China’s Financial Reforms: Why Dysfunctional Banking Survives' Hong Kong Institute of Monetary Research Working Paper No. 02/2012

Government of the Special Administrative Region of Hong Kong, Financial Secretary’s Office, Economic Reports (Various years 2004-2012)

Hope, N. \& Hu, F. 2006. 'Reforming Chinese banking: how much can foreign entry help?' Center for International Development, Stanford University. Working Paper No. 276.

Huang, Y. 2008. Capitalism with Chinese Characteristics, New York: Cambridge University Press.

Huang, Y. and K. Tao. 2011. 'Causes of and Remedies for the People’s Republic of China's External Imbalances: The Role of Factor Market Distortion’ Asian Development Banking Institute Working Paper Series No. 279

Huang, Y., X. Wang, Q. Gou, and D. Wang. 2011. Liberalisation of China's Capital Account Paper for NYU Conference on China’s Capital Markets, 31 ${ }^{\text {st }}$ May 2011.

Jao, Y.C. 1983. 'Hong Kong’s Role in Financing China’s Modernisation' in China and Hong Kong: The Economic Nexus, Youngston, A.J. (Ed) Hong Kong: Oxford University Press, $14-67$

Kose, M, E. Prasad, K. Rogoff, and S. Wei, 2006. “Financial Globalisation: A Reappraisal” IMF Working Paper (WP/06/189).

Olson, M., 1996. "Big Bills Left on the Sidewalk: Why Some Nations are Rich and Others Poor” Journal of Economic Perspectives, 10 (2): 3-24.

Ostry, J.D, A. Ghosh, K. Habermeier, M. Chamon, M. Qureshi, \& D. Reinhardt. 2010). 'Capital Inflows: The Role of Controls’ IMF Staff Position Note, $19^{\text {th }}$ February 2010 SPN/10/04

Peoples Bank of China. 2011, Monetary Policy Report, Quarter 1.

Kose, M, Prasad, E. K. Rogoff, \& S. Wei, 2006. Financial Globalisation: A Reappraisal” IMF Working Paper (WP/06/189).

Kueh, Y.Y. \& C. Howe. 1984. ‘China’s International Trade’ The China Quarterly, 100 (December): 813-848

Kambara, T. \& Howe, C. 2007. China and the Global Energy Crisis. Cheltenham: Edward Elgar. 
Kydland, F. \& E. Prescott, 1977. 'Rules rather than Discretion' Journal of Political Economy, Vol. 85 (3): 473-491.

Lardy, N.R. 1992. Foreign Trade and Economic Reform in China 1978-1990. Camrbidge

McCauley, R.N. 2011. 'The internationalisation of the Renminbi,' paper presented at Hong Kong Institute for Monetary Research $14^{\text {th }}$ of January 2011.

Prasad, E. K. Rogoff, S. Wei and M. Kose, 2003. Effects of Financial Globalisation on Developing Countries: Some Empirical Evidence” IMF

Reardon, L.C. 2002. The Reluctant Dragon: Crisis Cycles in Chinese Foreign Economic Policy, Seattle: University of Washington Press

Schenk, C. 2009. The Banking and Financial Impact of the 1967 riots in Hong Kong, in May Days in Hong Kong Emergency and Riot in 1967, Bickers, R. and R. Yep (eds), 105126. Hong Kong: Hong Kong University Press.

Solinger, D.J. 1993. China's Transition from Socialism: Statist Legacies and Market Reforms 1980-1990, Armonk, New York: M.E.Sharpe.

Sung, Y.W. 2005. The Emergence of Greater China: The Integration of Mainland China, Taiwan and Hong Kong, Palgrave Macmillan: Basingstoke

Taylor, A. (2012) ‘The Great Leveraging’ NBER Working Paper Series, Working Paper: 18290

Tobin, D. (2011) 'Austerity and Moral Compromise: Lessons from the Development of China’s Banking System’ World Development, 39 (5), pp 700-711.

Xinhua News Agency (NCNA) 
Tables and Figures

Table 1: Development of the RMB Off-Shore Deposits

\begin{tabular}{|c|c|c|c|c|c|c|c|}
\hline Year & Quarter & $\begin{array}{l}\text { Total } \\
\text { RMB } \\
\text { Deposits } \\
\text { (million) }\end{array}$ & Institutions & $\begin{array}{l}\text { Demand } \\
\text { Deposits }\end{array}$ & $\begin{array}{l}\text { Time } \\
\text { Deposits }\end{array}$ & $\begin{array}{l}\text { Trade } \\
\text { Settlement }\end{array}$ & $\begin{array}{l}\text { Trade } \\
\text { Settlement } \\
\text { as \% RMB } \\
\text { Deposits }\end{array}$ \\
\hline 2004 & 4 & 12,127 & 38 & 5,417 & 6,710 & & \\
\hline 2005 & 4 & 22,585 & 38 & 10,619 & 11,966 & & \\
\hline 2006 & 4 & 22,722 & 38 & 12,228 & 11,175 & & \\
\hline 2007 & 4 & 33,400 & 37 & 22,539 & 10,861 & & \\
\hline 2008 & 4 & 56,061 & 39 & 38,119 & 17,942 & & \\
\hline 2009 & 4 & 62,718 & 60 & 40,662 & 22,056 & 1,757 & 2.8 \\
\hline 2010 & 4 & 314,938 & 111 & 117,573 & 197,365 & 263,238 & 83.6 \\
\hline 2011 & 4 & 588,529 & 133 & 176,398 & 412,132 & 585,488 & 99.5 \\
\hline 2012 & 1 & 554,317 & 135 & 156,788 & 397,528 & 571,176 & 103.0 \\
\hline 2012 & 2 & 557,710 & 133 & 136,616 & 421,094 & 641,907 & 115.1 \\
\hline
\end{tabular}

Source: Financial Secretary’s Office (Hong Kong), Economic Report (Chapter 4).

Table 2: Current and Capital Account Flows as a \% of GDP (2005-2001)

\begin{tabular}{lrrrrrrr}
\hline & $\mathbf{2 0 0 5}$ & $\mathbf{2 0 0 6}$ & $\mathbf{2 0 0 7}$ & $\mathbf{2 0 0 8}$ & $\mathbf{2 0 0 9}$ & $\mathbf{2 0 1 0}$ & \multicolumn{2}{c}{$\mathbf{Q 0 1 1}$} \\
\hline Current account & 7.13 & 9.21 & 10.64 & 9.43 & 5.95 & 5.15 & 2.82 \\
\hline $\begin{array}{l}\text { Capital \& Financial } \\
\text { Account }\end{array}$ & 2.79 & 0.37 & 2.10 & 0.42 & 2.90 & 3.81 & 4.99 \\
\hline FDI & 3.51 & 2.88 & 3.96 & 3.27 & 1.57 & 3.12 & 3.11 \\
\hline OFDI & -0.50 & -0.66 & -0.48 & -1.18 & -0.88 & -1.02 & -0.69 \\
\hline Securities & -0.22 & -2.49 & 0.53 & 0.94 & 0.78 & 0.40 & 0.37 \\
\hline Other Investments & -0.18 & 0.49 & -1.99 & -2.68 & 1.36 & 1.22 & 2.12 \\
\hline Currency \& Deposits & 0.14 & 0.03 & 0.92 & -0.68 & 0.33 & 0.04 & 0.65 \\
\hline Errors and Omissions & -0.74 & -0.47 & 0.47 & -0.58 & -0.87 & -1.01 & -0.32 \\
\hline
\end{tabular}

Source: State Statistical Bureau (2005-2010) and State Administration for Foreign Exchange (2011, Q3) 
Figure 1: Hong Kong Renminbi Deposits: Time vs. Demand

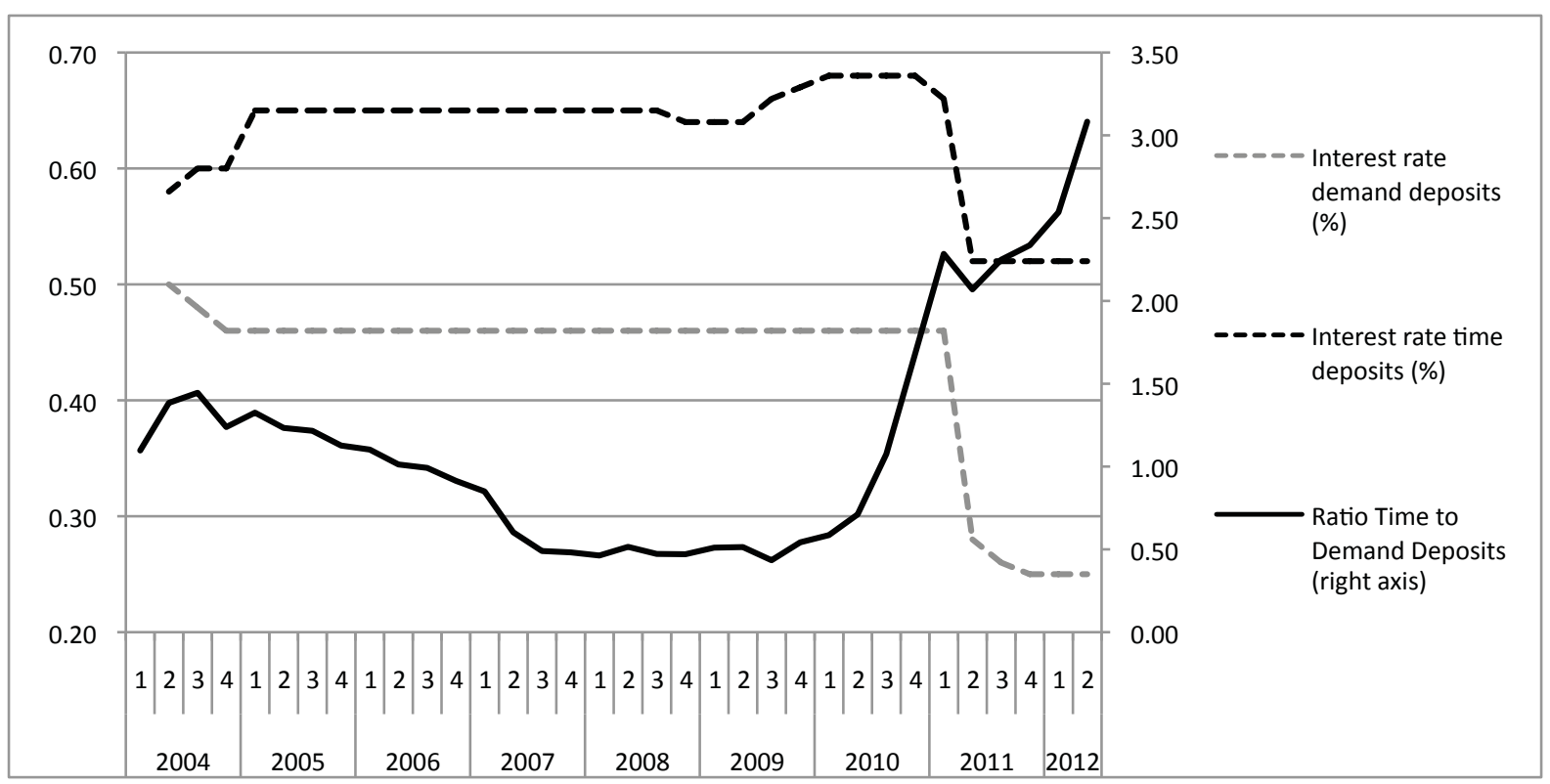

Source: Hong Kong Financial Secretary Economic Report. Interest rates are based on a Hong Kong Monetary Authority survey of banks

Figure 2: Ratio Advances to Deposits (Bank of China (Hong Kong)) and PRC Trade to GDP (\%) 1964-1980

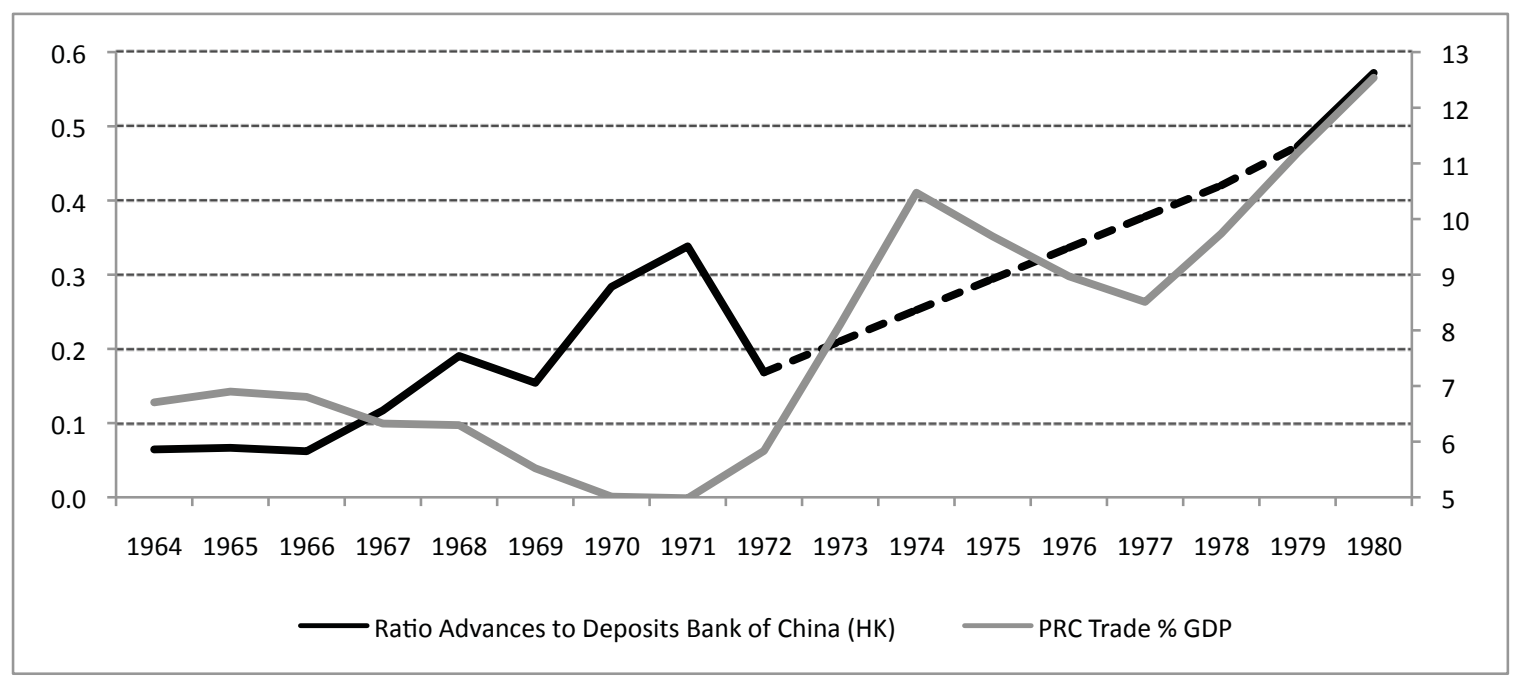

Source: Trade data and National Income data is from National Bureau of Statistics of China. Banking data for 1964-68 were derived from the statistical returns from licensed banks collected monthly by the Banking Commission and preserved in the following Hong Kong Public Records Office files: HKRS163-1-3273 ‘Banking Statistics Various 1965’. HKRS163-1-3274 ‘Banking Statistics Various - 1966’, HKRS163-1-3275 'Banking Statistics Various - 1967’, HKRS163-1-3276 ‘Banking Statistics Various’. Data for 1979-1980 is calculated based on data in Jao (1983: 68-71). Data for years 1973 to 1978 is not available. 